\title{
Faces da exemplaridade no Cato Maior de Cícero
}

Matheus Trevizam

Universidade Federal de Minas Gerais

Quod senior loquitur omnes consilium putant.

"O que o velho diz todos consideram sensato"

Publílio Siro, Máximas, Q54

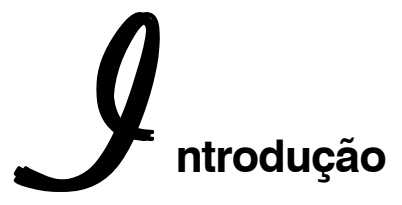

A antiga sociedade romana pautou-se, sobretudo, por critérios de tradicionalismo. ${ }^{1}$ Com isso, não queremos dizer que, dos longínquos momentos da fundação da Cidade até os tempos finais da cultura pagã, já às portas da Idade Média, mudança e "evolução" alguma se tenham introduzido em Roma, pois importantes fenômenos históricos como a consolidação das letras latinas pelo influxo helenístico, ${ }^{2}$ durante os séculos da conquista da bacia Mediterrânea (III a II

${ }^{1}$ Cf. esclarecedoras palavras de Pierre Grimal (2009, p. 71): A virtude essencial, capital, para um romano, é precisamente a que responde mais diretamente ao ideal camponês: a virtude de "permanência". Considera-se conforme com o bem tudo o que tenha por efeito manter a ordem existente, a fecundidade da terra, a esperança de uma boa colheita, a repetição dos anos, a renovação regular da raça, a estabilidade da propriedade. Condena-se, pelo contrário, tudo o que seja anárquico, inovador, tudo o que ameace a regularidade dos ritmos, tudo o que desenraize.

${ }^{2}$ GRIMAL, 1994, p. 85ss. 
a.C.), a crescente influência da filosofia sobre as mentalidades ${ }^{3}$ ou mesmo a gradual conversão do Império ao cristianismo ${ }^{4}$ atestam o contrário.

${ }^{3}$ Data de 155 a.C. o contato "inaugural" - e algo desarmonioso - de Roma com a filosofia, já que a visitaram em embaixada, então, Carnéades (o chefe da Nova Academia), o estoico Diógenes e o peripatético Critolau: apesar do grande sucesso de suas conferências com o público, o senado, instigado por Catão, o Velho, teve por mais seguro coibir-lhes a estada na Cidade; não se podia, enfim, tolerar a liberdade expressiva de homens "capazes de persuadir de tudo o que desejassem" (ROBERT, 2002, p. 286). Nesse mesmo século II a.C., porém, por influência de homens cultivados, cuja formação, aberta ao helenismo, também contemplara a filosofia, estabelecem-se em Roma meios nos quais circulava abertamente o pensamento abstrato grego; um exemplo contundente é o do célebre "Círculo dos Cipiões", agregado em torno da figura do aristocrata Públio Cornélio Cipião Emiliano (185-129 a.C.), e que contou com o brilho dos poetas Terêncio e Lucílio, do historiador Políbio e do estoico Panécio (ROBERT, 2003, p. XV). No séc. I a.C., apenas para citar alguns pontos-chave, Tito Lucrécio Caro compõe o monumental De rerum natura, obra inteira votada a expor as doutrinas da física epicurista, e Cícero, em iniciativa pioneira, a qual não desdenha inclusive vultosos esforços para constituir um vocabulário romano da filosofia, engendra seu vasto corpus especulativo (GRIMAL, 2009, p. 155-156). Durante o período augustano e o prosseguir da Era imperial, se não for demasiado simplificar desta maneira, teve significativa proeminência cultural e política o estoicismo [GRIMAL, 2009, p. 80-81: “O papel preponderante dos senadores adeptos do estoicismo durante as vicissitudes do regime no século I da nossa era mostra bem a concordância profunda existente entre esta filosofia, expressão por excelência da vida moral romana, e o principado augustano. Sempre que os imperadores se desviam da linha política augustana, a oposição estoica desperta; pelo contrário, os Príncipes podem contar com a colaboração desta parte do Senado quando se remetem aos princípios de Augusto... (...) O reinado dos Antoninos marca o triunfo desta monarquia iluminada de inspiração estoica na qual, a despeito de todas as revoluções, sobreviveu o velho espírito romano"].

${ }^{4}$ GIORDANI, 1968, p. 323ss. 
Entretanto, para os latinos, como veremos pelo testemunho prático do Cato Maior de Cícero, inovar(-se) não necessariamente significou a completa substituição de antigos valores ou modos de pensamento por outros mais "atuais", antes se dando tal processo pela via da aculturação conciliatória entre certas bases bem estabelecidas em sua sociedade e o novo. No plano letrado, os exemplos precoces de Lívio Andronico e Ênio comprovam que a decisiva influência grega sobre o gênero épico não bastou para que se erradicassem todas as tradições pátrias das linhas de obras emblemáticas como a Odusia e os Annales: em que pese à incorporação de elementos homéricos também representados pelo detalhe introdutório da invocação poética a um Nume tutelar ou pelo metro hexâmetro datílico, a substituição da "Musa" helênica pela Camena local e o pronunciado gosto itálico pelas aliterações, ${ }^{5}$ respectivamente encontráveis nos poemas de Andronico e Ênio, são indícios do caráter parcial do fluxo das mudanças culturais em Roma.

Sem intenções de elaborar um itinerário preciso das complexas relações entre a sociedade romana e a filosofia, por outro lado, dispomos de alguns dados que nos parecem

${ }^{5}$ POCIÑA, 2007, p. 16: Si hay que calificar la "Odusia" de algún modo, nosotros diríamos que es la actualización latina de una magnífica herencia llegada de Grecia, una actualización que no queda restringida a inteligentes latinizaciones, como "Moúsa" en "Camena", "Mnemosýne" en "Moneta", "Moîra" en "Morta", etc., sino que llega a una interpretación personal del texto homérico./ LEUMANN, 1988, p. 141 e 144: Però la tradizione stilistica indigena non ha contribuito troppo allo sviluppo della lingua poetica neviana, limitandosi a fornire espressioni sacrali come "diuis gratulabatur", incisivi asindeti come "urit populatur uastat", alliterazioni come "uicissatim uolui uictoriam" (grifos nossos)./ Egli usa e abusa dell'alliterazione, "accipe daque fidem foedusque feri bene firmum" [Ann. 32 Vahl]; "Africa terribili tremit horrida terra tumultu" [Ann. 310]; "o Tite tute Tati tanta tyranne tulisti" [Ann. 109]. 
também comprovar algum tradicionalismo da parte dos receptores de tal componente cultural estrangeira: além da supracitada expulsão da embaixada dos filósofos gregos durante a censura de Catão, ${ }^{6}$ Tito Lucrécio Caro dá mostras, no De rerum natura, de que entende os conteúdos deste seu poema epicurista capazes de produzir receio ou estranhamento sobre o público, ${ }^{7}$ dado, inclusive, o teor antirreligioso do texto. ${ }^{8}$ Ora, reservas de certas elites cultas à parte, sabemos que os elementos tradicionais da religião romana, como o cadenciado andamento e presença dos ritos, continuaram a integrar o aparato político do Estado até a entrada daqueles cristãos, a partir do século IV d.C.;

${ }^{6}$ Cf. supra nota 3.

${ }^{7}$ De rerum natura I 80-82: Illud in his rebus uereor, ne forte rearis/ impia te rationis inire elementa uiamque/ indugredi sceleris (...). - "Isto temo quanto a esses assuntos, que talvez creias / abordar elementos ímpios da doutrina e num caminho/ de crime adentrar (...)" LVCRETI, 2009 (trad. nossa).

${ }^{8}$ GALE, 2001, p. 47-48: If, as has been argued, the main theme of the three books is the foolishness of fearing death, there are also hints of what is to come in Books 4-6. Lucretius' second major task is to free us from superstition, by which he means, essentially, the belief that the gods have anything to do with the human world, and that we can influence them either in our favour or to our detriment. In a sense, the whole poem implicitly supports this view: the entire physical system is concerned to demonstrate that all natural phenomena can be accounted for in purely mechanistic and materialistic terms, without the need for divine intervention of any kind.

${ }^{9} \mathrm{O}$ primeiro imperador cristão foi Constantino, supersticiosamente convertido após vitória militar contra Magêncio, seu maior opositor político (312 d.C.). Contudo, como observa Mário Curtis Giordani (1968, p. 348), não foi essa uma conversão desprovida de ambiguidade, pois o imperador jamais abdicou do título de Pontífice, "conservou um pé em cada campo e, até seu leito de morte, permaneceu, estritamente falando, fora da Igreja, da qual não foi um fiel e nem mesmo um catecúmeno. 
desse modo, o Neo-acadêmico, ou, em outros termos, probabilista Cícero $^{10}$ não hesitou (como Plínio) em aceitar o Augurado quando já contava mais de cinquenta anos, ${ }^{11}$ e os imperadores quiseram sempre reservar para si as prerrogativas do Pontificado Máximo, vale dizer, a chefia suprema do culto pátrio de Roma. ${ }^{12}$

Humanamente, por outro lado, os antigos romanos também deram mostras de se pautarem por tradições que levavam em conta a auctoritas ${ }^{13}$ dos ancestrais. Os cortejos fúnebres dos patrícios, com efeito, exibiam as imagines dos antepassados, "máscaras de cera pintadas ao natural e adaptadas a bustos: na base dos bustos, uma inscrição, titulus, lembra as funções e os feitos

Mas tudo isso não deve fazer rejeitar a realidade de sua "conversão": desde 312, Constantino acredita no Cristo Redentor, cujo monograma ele adota nos escudos de seus soldados antes de fixá-lo sobre seu capacete e sobre seu estandarte e de fazer figurá-lo em moedas; a partir de 312, também, devotou-se à Igreja honrando-a, protegendo-a e favorecendoa com todas as suas forças".

${ }^{10}$ NARDUCCI, 2010, p. 181: Nel precipitare della crisi dei valori consolidati, l'opzione per lo scetticismo si rivelò a Cicerone come la più utile a impostare una ricerca aperta, libera da preclusioni, tesa a fare emergere, dal confronto tra le diverse posizioni, $i$ criteri di una morale aliena da certezze assolute e da un anacronistico rigorismo, ma sufficiente a orientare correttamente l'azione. L'adesione al metodo neoaccademico significava per Cicerone autonomia di ricerca individuale, e libertà dal principio di autorità che aveva per conseguenza la chiusura settaria delle scuole contrapposte.

${ }^{11}$ PEREIRA, 2010, p. 115 e 116, sobretudo nota 23.

12 BORNECQUE e MORNET, 1976, p. 75.

${ }^{13}$ Por esse conceito caracteristicamente romano, não devemos entender um equivalente direto da palavra portuguesa "autoridade", já que, enquanto ela designa indefinida o "direito ou poder de ordenar" (Dicionário Houaiss da língua portuguesa. 1 $1^{\text {a }}$. edição. Rio de Janeiro: Objetiva, 2009), a ideia envolvida pelo termo em latim mantém mais nexos com noções de peso moral ou prestígio para influir sobre realidades e indivíduos (ROCHA PEREIRA, 2009, p. 362). 
memoráveis da personagem". ${ }^{14}$ As imagines eram ainda mantidas junto aos átrios das casas, nas alae ("galerias"), ${ }^{15}$ como espécie de signo concreto da perenidade das principais famílias, pois, com sua "presença", asseguravam materialmente o estabelecimento de vínculos entre passado e presente.

Tal respeito aos valores ancestrais, base do mos maiorum, ${ }^{16}$ ou seja, o conjunto de preceitos e normas de vida afinado com os costumes dos antigos, justifica, assim como as alae das casas patrícias se tornaram repositórios físicos de um passado não negligenciável, que a memória coletiva se tenha constituído em "morada" de personagens históricas (ou de seus gestos) cujos méritos lhes favoreceram a secular "sobrevivência". Aludimos, com essas palavras, ao próprio tema do presente artigo, pois que se trata de evocarmos, sob a rubrica instrumentalizadora da "exemplaridade", quer a geral eleição de tipos heroicos representativos dos grandes valores comuns (fides, pietas, fortitudo...), quer o gosto romano pelo recolho e ciosa conservação dos exempla maiorum; pela última expressão, entendemos os microrrelatos dos ditos e feitos memoráveis dos pregressos, ${ }^{17}$ os

${ }^{14}$ BORNECQUE e MORNET, 1976, p. 85.

${ }^{15}$ BORNECQUE e MORNET, 1976, p. 147.

16 ROCHA PEREIRA, 2009, p. 357-361: “Os Romanos tinham como suporte fundamental e modelo do seu viver comum a tradição, no sentido de observância dos costumes dos antepassados, 'mos maiorum'. Esta ideia é, pelo menos, tão antiga com Ênio, em fragmento muitas vezes citado: 'Nos costumes e varões antigos se apoia o Estado Romano'."

${ }^{17}$ DAVID, 1980, p. 67: L' «exemplum», la petite histoire courte qui rappelle un fait passé de la vie d'un grand homme, joue donc un rôle important dans la stratégie de l'orateur./ Cf. também definição da Rhetorica ad Herennium IV, 62: Exemplum est alicuius facti aut dicti praeteriti cum certi auctoris nomine proposito. Id sumitur isdem de causis, quibus similitudo. Rem ornatiorem facit, cum nullius rei nisi dignitatis causa sumitur; apertiorem, 
quais, tidos por modelos, acabaram por constituir duradouro patrimônio da latinidade.

De todo modo, cultuar heróis ou reportar exemplarmente com fins ilustrativos de argumentos, de aumento da credibilidade discursiva, ou outros - gestos de homens do passado sempre significou para os romanos antigos retomar, de um mesmo manancial da tradiçãa, parâmetros sociais reguladores. $\mathrm{O}$ acompanhamento dessas duas faces da exemplaridade no Cato Maior, de Cícero, auxiliar-nos-á a divisar, de modo parecido com o já apontado de passagem a respeito da influência parcial das letras e da filosofia helênica sobre o espírito dos latinos de diferentes épocas, que o âmbito humano amiúde não prescindiu, em sua cultura, da sólida ancoragem em princípios locais bem assentados, e até consagrados, de conduta.

\section{A escolha de Catão, o Velho, para porta-voz das doutrinas do De Senectute e o caráter exemplar dessa personagem na cultura romana}

A escolha de Catão, o Velho, para porta-voz das ideias expressas no diálogo ciceroniano do De Senectute jamais poderia, levando-se em conta fatores contextualmente históricos

cum id, quod sit obscurius, magis dilucidum reddit; probabiliorem, cum magis ueri similem facit; ante oculos ponit, cum exprimit omnia perspicue, (ut) res prope dicam manu temptari possit. - "É o exemplo citar algum feito ou dito passado anunciando-se o nome exato do autor. Emprega-se pelos mesmos motivos que a comparação. Faz mais ornado o pensamento, quando por nenhum outro motivo se emprega a não ser para torná-lo belo; mais claro, ao iluminar o que for obscuro; mais convincente, quando o faz mais verossímil; põe diante dos olhos ao exprimir tudo obviamente, de modo, por assim dizer, que se pode tocar o pensamento com os dedos" (apud DAVID, 1980, p. 71, trad. nossa). 
ou a biografia de Cícero, ser considerada mera casualidade. De início, importa talvez retomar o dado de que os entornos da escrita da obra ${ }^{18}$ não se constituíram, para Cícero, numa época exatamente risonha de sua vida: com efeito, divorciado de Terência (45 a.C.) após um longo matrimônio, de novo se casa com a jovem Publília em frágil união, que não tardou em desfazer-se, ${ }^{19}$ por outro lado, sua filha dileta, Túlia, morre bruscamente no mesmo ano, causando-lhe profundo desalento. ${ }^{20}$

Quanto ao plano de sua carreira política, após o dúbio sucesso $^{21}$ de seu consulado em 63 a.C. e o proconsulado na

${ }^{18}$ A data de composição do diálogo Cato Maior são os inícios de 44 a.C. Para uma cronologia mais ampla das obras filosóficas ciceronianas, cf. ANDRÉ, 1977, p. 54-55: 46- Eloge de Caton/ Paradoxa; 45- février: Consolatio (inspirée par la mort de Tullia); 45- mai à juillet: Academica / Academica priora/ Academica posteriora; 45- fin juin: De finibus / 45juin à août: Tusculanes / traduction du Timée de Platon; 45- août: De natura deorum; 44- peu avant ou après Ides de mars: Cato Maior; 44autour de Ides de mars: De diuinatione; 44- avril-mai: idée du De fato; 44- été: Laelius De amicitia, De gloria; 44-43- automne-hiver: De officiis. ${ }^{19}$ GRIMAL, 1986, p. 349: Et Publilia, demandera-t-on? D'elle il n'est plus question. Dès la mort de Tullia, Cicéron lui a déclaré son désir d'être seul, et il l'a renvoyée à Rome. Il sentait - sans doute avec raison - que la jeune femme, jalouse de Tullia, avait éprouvé quelque satisfaction de cette mort, et ce sentiment lui rendait impossible même de la voir.

${ }^{20}$ GRIMAL, 1986, p. 349: L'enfant de Tullia naquit vers la mi-janvier. La date exacte n'en est pas connue. Bientôt après, Cicéron, Tullia et Publilia partirent pour Tusculum. Là, vers la mi-février, Tullia mourut. Sa santé, pourtant, n'avait pas donné d'inquiétude. Cette mort soudaine, inattendue, bouleversa profondément Cicéron.

${ }^{21}$ Como sabemos, a mais importante consequência para Cícero de seu maior feito durante o próprio consulado, o desmascaramento da Conjuração de Catilina e a sumária condenação de vários envolvidos, foi o exílio [NARDUCCI, 2010, p. 92-93: Verso la fine di gennaio del 58 Clodio aveva presentato un progetto di legge («lex Clodia de capite ciuis 
Cilícia (52 a.C.), ${ }^{22}$ já no retorno do exílio (58 a.C.), sabemos que jamais voltou a desfrutar de segura influência em Roma; os meses subsequentes aos Idos de março de 44 a.C., quando obteve fugaz proeminência no senado e proferiu temerariamente as Filípicas contra Marco Antônio, ${ }^{23}$ apenas representaram, nesse sentido, um efêmera ilusão de restauro da antiga posição. Ainda em vida de César, que se tornaria ditador vitalício e que desbaratou, na batalha de Munda (45

Romani») che prevedeva l'esilio per chi avesse condannato a morte un cittadino romano senza concedergli di appellarsi al popolo. Sul piano giuridico, il provvedimento riapriva il vecchio conflitto tra l'inviolabilità dei diritti dei cittadini e l'ampiezza dei poteri concessi ai consoli dall'emanazione del "senatus consultum ultimum", che sospendeva la legalità costituzionale. Sentendosi direttamente minacciato dalla legge di Clodio, Cicerone inizialmente tentò, senza successo, il ricorso a una mobilitazione generale: molti senatori e cavalieri indossarono vesti a lutto per significare il loro appoggio al salvatore della "res publica". Ma alcuni tra gli ottimati, come Ortensio, gli consigliarono un esilio volontario, soprattutto, a quanto pare, per allontanare il pericolo di un conflitto civile.]

${ }^{22}$ NARDUCCI, 2010, p. 155: Nonostante il tedio che ostentava per il lavoro amministrativo, il periodo in cui governò la Cilicia fu uno dei più luminosi della sua vita; tutelò i diritti dei suoi sudditi, sforzandosi di resistere alle pretese talora esose dei prestatori romani (fra i quali vi era l'adamantino Bruto); condusse con successo piccole operazioni militari contro ribelli e banditi, per le quali invano si piccò di ottenere un trionfo; infine riuscì, senza violare quella che il governo romano considerava la legalità, ad arricchirsi in maniera molto consistente, anche se non favolosa.

${ }^{23}$ NARDUCCI, 2010, p. 205: Con sapiente varietà, le "Philippicae" alternano i toni appassionati e magniloquenti, la solennità del dolore e dell'indignazione, con l'argomentare pacato e con i vivacissimi quadri satirici di Antonio, dei suoi turpi traffici con i falsi decreti di Cesare, del suo seguito di miserabili figuri assetati del sangue dei "boni" $e$ rapacemente incombenti sui loro patrimoni. 
a.C.), os derradeiros focos de resistência a si após Farsália, ${ }^{24}$ os esforços de Cícero para tentar aproximar-se efetivamente do poder não surtiram grandes efeitos, ${ }^{25}$ por fim, suas tentativas de valer-se de Otaviano, o herdeiro político de César, também em favor do senado e dos assassinos do ditador foram tragicamente frustradas diante da decisão daquele pela causa de Marco Antônio e da instável instauração do Segundo triunvirato. ${ }^{26}$

Ora, a figura de Catão, tal como recriada por Cícero nas linhas deste diálogo, que se inscreve na tradição "gerontológica" (e consolatória) da literatura antiga, ${ }^{27}$ vem responder enérgica e positivamente, com a forte carga simbólica a envolvê-lo no imaginário romano, não só aos males pessoais do autor, mas

${ }^{24}$ GIORDANI, 1968, p. 59.

${ }^{25}$ ROBERT, 2003, p. IX: Courant mai - 45, après la victoire de Munda, il décide d'écrire à César pour lui donner quelques conseils, comme cela se fait couramment à cette époque (Salluste fera de même). Mais des amis du nouveau maître de Rome lui déconseillent vivement d'envoyer sa lettre pour éviter les foudres césariennes. Cicéron, dépité, sent poindre le tyran sous l'armure du dictateur. Il comprend qu'il doit se taire.

${ }^{26}$ Esta decisão política de Otaviano, o futuro imperador Augusto, acabou dando forças totais a Marco Antônio para vingar-se das invectivas ciceronianas das Filípicas. Assim, ele inclui Cícero entre os proscritos e faz assassiná-lo em primeiro de dezembro de 43 a.C., quando o orador tentava fugir da Itália para autoexilar-se na Macedônia (NARDUCCI, 2010, p. 206).

${ }^{27}$ PARKIN, 2003, p. 64-65: Although Cicero states that he knows that Atticus bears the "onus" of old age "modice ac sapienter", it is "consolatio", not praise, that is the primary aim to which Cicero alludes in dedicating the dialogue to his friend ("de Sen." 1.1-2). (...) While following a Greek tradition that he admired greatly, Cicero did more than just produce a polished literary exercise (and it needs to be remembered that this is above all a work of literature, not a social document). He also sought to provide real "consolatio" for his own age, upset and almost overwhelmed as he was at the time by personal worries and political uncertainties. 
também, é evidente, às várias incertezas coletivas dos tempos. Em rememoração sumária de alguns aspectos da vida e personalidade de Catão, diríamos que nasceu em 234 a.C. em Túsculo, no país Sabino, no seio de uma modesta família da ordem equestre, porém da gens plebeia Pórcia. Após uma infância austera, em que trabalhou com suas mãos nas terras paternas, ${ }^{28}$ ingressou nas milícias romanas aos dezessete anos, ${ }^{29}$ na ocasião das invasões de Aníbal contra a Itália, tendo-se destacado belicamente a ponto de já aos vinte e quatro anos, tornar-se tribuno militar na Sicília. ${ }^{30}$

Aos vinte e oito anos, depois desses sucessos e de exercitar-se na província como orador, atraiu a simpatia de Lúcio Valério Flaco, personagem proeminente da nobilitas romana, e transferiu-se para a Cidade, ${ }^{31}$ onde o aguardava o

${ }^{28}$ Apud DELLA CORTE, 1969, p. 12 Ego iam a principio in parsimonia atque in duritia atque (in) industria omnem adulescentiam meam abstinui agro colendo, saxis Sabinis, silicibus repastinandis atque conserendis. "Quanto a mim, desde o princípio resguardei toda minha juventude na parcimônia, no rigor e na atividade cultivando os campos, rochas sabinas, recavando e semeando o cascalho" (Catão, frag. 128 Malc., trad. nossa).

${ }^{29}$ PLUTARCO, 2011: Catone I, 8 - F hs ilgar a utol epta ka idek a gegonw) efh thh prwthnstrateus as qai strateian, periloh Annibaj xrohon eutuxw epef I ege thh Ital ian. - Egli stesso racconta di aver avuto diciassette anni al tempo della sua prima campagna militare, quando Annibale, vittorioso,faceva ardere l'Italia.

${ }^{30}$ Apud DELLA CORTE, 1969, p. 16: Q. Fabio M. Claudio consulibus tribunus militum in Sicilia fuit. - "No consulado de Q. Fábio e M. Cláudio, foi tribuno militar na Sicília" (Nep., Cato I, 2, trad. nossa). ${ }^{31}$ Apud DELLA CORTE, 1969, p. 17: Inde hortatu L. Valerii Flacci, quem in consulatu censuraque habuit collegam... Romam demigrauit in foroque esse coepit. - "Depois, por convite de L. Valério Flaco, que teve como colega no consulado... mudou-se para Roma e começou a frequentar o foro" (Nep., Cato I, 1, trad. nossa). 
prosseguimento dos demais degraus do cursus honorum. Dessa maneira, aos trinta e cinco anos, Catão tornou-se edil da plebe e instituiujogos, ${ }^{32}$ enquanto, aos trinta e seis, foi pretor da Sardenha, demonstrando, no comando da ilha, postura de "esforço e parcimônia". ${ }^{33}$ Vemo-lo cônsul, no alto da carreira pública dos cidadãos, aos trinta e nove anos, ${ }^{34}$ e censor aos cinquenta. Notabilizou-se, durante o desempenho dessa última função tradicionalmente caracterizada, além de pelo recenseamento dos cidadãos e de seus bens, pelo "controle moral dos méritos e dos costumes individuais",- 35 por significativa fama de rigor. Assim, expulsou do senado por falta de decoro até personagens pertencentes à nata da aristocracia, como um certo Lúcio Quínctio Flamínio, irmão de Tito, o general liberador da Grécia após a vitória contra Filipe V da Macedônia (197 a.C.).

Com efeito, esse fizera levianamente executar a espada, investido do consulado, um chefe gaulês que se apresentara com os filhos diante dele a fim de solicitar garantias de segurança. O motivo de tal arbitrariedade fora o desejo, segundo a versão narrada por Tito Lívio, de oferecer a certo moço prostituído que o acompanhava uma compensação pessoal, já que esse último se queixara de ter sido tirado, em

${ }^{32}$ Apud DELLA CORTE, 1969, p. 23: Aedilis plebis factus est cum C. Heluio. - "Tornou-se edil plebeu com C. Hélvio" (Nep., Cato I, 3, trad. nossa).

${ }^{33}$ Apud DELLA CORTE, 1969, p. 23: Praetor prouinciam obtinuit Sardiniam. - "Investido do pretorado, obteve a província da Sardenha" (Nep., Cato I, 4, trad. nossa).

${ }^{34}$ PLUTARCO, 2011: Catone X, 1 - Npatoj delmetalf I a kkou 0 u $\mid$ l eri/ ou toufil ou kailsunhqouj a podeixqei", el a ke twa eparxiwahk Entol I\$pani/ a n Rwma iei kal ousin.- Eletto consule con il suo grande amico Valerio Flacco, ebbe in sorte la provincia che i Romani chiamano Spagna Citeriore. 35 ROBERT, 2002, p. 194. 
Roma, de um sangrento espetáculo de gladiadores a fim de servir ao amo. ${ }^{36}$

Entre seus feitos militares, por outro lado, há que se destacar a vitória contra os nativos das Espanhas Citerior e Ulterior, num levante por ele debelado e do qual resultou seu triunfo em 194 a.C. ${ }^{37}$ Além disso, os romanos dispersaram, durante seu tribunato militar (191 a.C.), as tropas do rei Antíoco III da Síria, que o exército latino atraiçoara junto ao desfiladeiro das Termópilas, inviabilizando, assim, as pretensões do soberano em território grego: ${ }^{38}$

La sorpresa era riuscita; sullo schieramento frontale, i Siriaci di Antioco, incalzato dai Romani e ferito, si davano alla fuga, $e$, inseguiti, per la natura impervia del luogo sdrucciolavano e cadevano lungo gli angusti sentieri giù dalle rocce, affogando nei pantani. ${ }^{39}$

Catão também se destacou culturalmente por representar a defesa das tradições romanas contra o crescente - e, na

${ }^{36}$ Cf. Tito Lívio Ab Vrbe condita XXXIX, 42, 5-12, apud ROBERT, 2002, p. 197.

${ }^{37}$ DELLA CORTE, 1969, p. 34.

${ }^{38} \mathrm{Na}$ verdade, porém, apenas em seguida Antíoco acabaria de todo derrotado nesta campanha (GIORDANI, 1968, p. 47: "Na Grécia, os etólios, descontentes com a parte que lhes coubera após a derrota de Filipe V, pedem o auxílio de Antíoco que desembarca na Tessália com um exército. Os romanos, auxiliados pelos aqueus, por Rodes, Pérgamo e pela própria Macedônia, batem Antíoco III nas Termópilas, obrigando-o a abandonar a península; destroem a frota selêucida em Coricos e Mionesos; aniquilam, sob o comando de Cipião, irmão do Africano, o exército de Antíoco III, em Magnésia de Sipilo na Ásia, em 189 a.C. Na Grécia, os etólios são definitivamente derrotados.").

${ }^{39}$ DELLA CORTE, 1969, p. 39. 
verdade, irrefreável -avanço do helenismo, ${ }^{40}$ de que foram grandes entusiastas, em sua época, os membros da família aristocrática dos Cipiões. ${ }^{41}$ Para os parâmetros dos tradicionalistas como ele, decerto pareciam inadequados à vida romana o gosto helênico pelo luxo, a "demasiada" dedicação às letras e não a afazeres mais "práticos", a "falta de firmeza" na palavra dada (em contraste com a fides caracteristicamente pátria), ${ }^{42}$ a moral "frouxa"... Um Públio Cornélio Cipião Africano, ainda, impetuoso vencedor do cartaginês Aníbal na batalha de Zama ${ }^{43}$ e, individualmente, destacado

${ }^{40}$ ROBERT, 2002, p. 234: Cependant, cette influence grecque due à l'appétit de jouissance et au luxe n'est sans doute pas celle qui marqua Rome le plus profondément. L'éducation de la jeunesse, plus encore que la soif de biens matériels, imprime dans les esprits une évolution durable. Depuis la fin du III siècle, la mode des précepteurs s'est développée dans les grandes familles aristocratiques. (...) Depuis cette époque, c'est un signe d'appartenance à la classe aristocratique que de confier ses enfants à un précepteur grec, chargé de son instruction. Le père de famille se décharge sur lui d'un soin qui pourtant, par tradition, dépend de lui. Caton, d'ailleurs, nous l'avons vu, refuse de se plier à cette nouvelle mode et éduque lui-même son fils.

${ }^{41}$ ROBERT, 2002, p. 235: Caton, alors consul en -195, avait déjà tenté de lutter contre cette évolution en s'opposant à l'abrogation de la loi Oppia. C'était le temps, nous l'avons dit, où Scipion l'Africain aimait se faire raser chaque matin et parader dans un costume grec, celui où son frère, vainqueur en Asie, préférait le surnom grec d'Asiagenes à celui d'Asiaticus, celui encore où Aemilia, femme de l'Africain, éblouissait la foule, lors des cérémonies, par la richesse de sa parure, la splendeur de son char, la théorie de vases d'or portés par une foule de serviteurs...

${ }^{42}$ ROBERT, 2002, p. 239-240.

${ }^{43}$ LE GLAY, VOISIN e LE BOHEC, 2008, p. 77: Since 210, the young Scipio had been attracting everyone's attention. Dispatched as proconsul to Spain (before he had held any other important office), he had recaptured Cartagena (New Carthage) and, while holding both Saguntum and Cartagena - the two principal maritime bases in the western Mediterranean - had simultaneously put an end to the Barcine empire and made the crossing 
demais para não despertar inquietude no senado, delineava-se com traços afins aos dos monarcas do Oriente - como o próprio Alexandre Magno! -, de modo que o apoio a tais homens na Cidade, acreditavam Catão e outros defensores políticos do mos maiorum, devia ser coibido. ${ }^{44}$ "Perigosas" e semelhantes concessões aos costumes estrangeiros, por sinal, determinaram seus embates públicos contra essa família, ${ }^{45}$ os quais só vieram

to Africa possible. Elected consul for 205, after a rough political battle in which supporters and adversaries of an African expedition opposed one another in the Senate, he obtained the province of Sicily, with the right to cross over to the African continent. He left for Africa in 204 with two legions and their auxiliaries, 35000 men in all, relying heavily on the help of the Numidian king Massinissa, with whom negotiations had long been going on. He landed near Utica and in the spring of 203 won a brilliant victory over the Punic forces. Carthage recalled first Mago, and then Hannibal, who landed near Hadrumetum (Susa) in the autumn. While attempts at negotiations were proceeding, Scipio made intensive preparations, drilling his troops in a tactic based on that of his opponent. With the decisive assistance of the Numidian cavalry, he won his great victory at Zama (near Ksar Toual Zammel in present-day Tunisia) on October 29, 202.

${ }^{44}$ ROBERT, 2002, p. 255: Il s'agit donc plutôt d'un conflit politique, voire idéologique entre deux catégories d'hommes, ceux qui s'appuient sur la tradition romaine, celle du «mos maiorum», dont Caton est le plus remarquable héraut, et ceux qui veulent faire évoluer le pouvoir romain en le personnalisant, suivant en cela l'exemple des grands monarques hellénistiques et préfigurant déjà ce que sera le principat, représentés notamment par Scipion l'Africain.

${ }^{45}$ DELLA CORTE, 1969, p. 52: L'azione politica, tenuto conto della personalità degli imputati, finì così Publio sdegnato lasciò Roma per ritirarsi a Literno, dove morendo fece incidere sulla sua tomba "ingrata patria, non hai neppure le mie ossa"; Lucio, rimasto solo e senza l'appoggio del fratello, fu facilmente eliminato dalle elezioni censorie e poi, durante la censura catoniana, privato persino del cavallo. 
a mitigar-se quando os Cipiões, no entender de Robert, abrandaram o próprio ímpeto inovador. ${ }^{46}$

Nem poderíamos omitir as iniciativas de Catão no âmbito oratório ou da composição escrita, pois também nessas facetas de sua atuação social deu mostras de apego às tradições latinas e de desejar pôr-se a serviço de Roma. ${ }^{47}$ Além dos discursos,

${ }^{46}$ ROBERT, 2002, p. 260: Il apparaît donc clairement que les relations entre Caton et les Scipions ont évolué parce que, d'abord, ceux-ci ont changé. Le jeune Émilien lui-même, qui se trouve l'héritier de deux familles, a subi l'influence de son père, et aussi de Caton que Paul-Émile lui conseillait de fréquenter et d'écouter. Et malgré son attachement à l'hellénisme dont il est imprégné depuis son enfance, il n'a rien oublié ni renié des valeurs ancestrales de Rome. Esse (Cipião) Emiliano a que Robert faz menção na passagem é, por sinal, um dos interlocutores fictícios de Catão no diálogo Cato Maior e, biologicamente concebido pelo general Paulo Emílio (230 a 160 a.C.), foi dado em adoção a Cipião, filho d'o Africano, assim se tornando membro da família aristocrática em pauta.

${ }^{47}$ Como ressaltou Pierre Grimal (1994, p. 118), as obras de Catão, antes de mais nada destinadas a cobrir aspectos práticos da vida romana (agricultura, direito, moral quotidiana...), inscrevem-se num verdadeiro programa de instrução dos cidadãos para atuarem na Cidade. Nesse sentido, embora um clássico estudo como aquele de Silvano Boscherini (Lingua e scienza greca nel "De agri cultura" di Catone. Roma: Edizioni dell'Ateneo, 1970) tenha demonstrado a inegável incorporação de saberes técnicos gregos ao De agri cultura, por exemplo, tratou-se, neste caso, de um texto composto por um latino - o próprio Catão - com vistas ao atendimento de necessidades informativas atinentes, também, a membros da sociedade romana, a saber, os patres familias suficientemente dotados pela fortuna para poderem dedicar-se aos cultivos segundo os parâmetros da "nova" economia agrária (aquela de produção intensiva e exportação de vinho e azeite, sobretudo, e não de cultivo e consumo local de grãos - MARTIN, 1971, p. 237ss.). 
plenamente inseridos no contexto maior de sua atuação política, ${ }^{48}$ e do De agri cultura, ${ }^{49}$ ele se dedicou a compor as Origines, obra de cunho histórico destinada a resgatar e valorizar o passado romano desde tempos longínquos,,$^{50}$ mais duas "monografias" técnicas especializadas (o De re militari e um tratado de direito civil), o Ad filium, identificado, na visão

${ }^{48}$ PERNOT, 2000, p. 130: Les discours de Caton accompagnent le cours de sa brillante carrière militaire et politique: harangues aux armées qu'il commanda en Espagne, messages diplomatiques lors de missions, à Athènes par exemple, remontrances sévères au cours de sa censure, nombreuses plaidoiries, adresses au Sénat et au peuple.

${ }^{49} \mathrm{O}$ De agri cultura, única obra catoniana que nos chegou em estado "completo", é uma coletânea de capítulos mais ou menos conexos sobre as artes agrárias (viticultura, oleicultura, ovinocultura...). Reflete, com o privilégio em suas páginas da viticultura e da oleicultura de exportação, os rumos expansionistas e comerciais da agropecuária itálica entre fins do terceiro século a.C. e o início do segundo séc. a.C. Ainda, com seu caráter muitas vezes sentencioso, centralizado na necessidade de racional comando do fundus rusticus pelos chefes e do trabalho duro pelos subordinados, além de religioso e frugal, espelha noções caras à latinidade, como aquela da superioridade moral dos camponeses - homens inclusive "propensos" a se tornarem fortes soldados - diante dos citadinos (MILES, 1980, p. 7).

${ }^{50}$ GRIMAL, 1994, p. 119-120: Le dernier ouvrage en prose de Caton, ses «Origines», qui furent écrites, si l'on en croit Cornélius Népos, «dans sa vieillesse»: commencées peut-être vers 172, les «Origines» n'étaient pas encore achevées lorsque mourut Caton. L'ensemble comprenait sept livres, et on peut, tant bien que mal, en reconstituer le contenu. (...) La connaissance du passé importe à ceux qui ont la responsabilité du présent et $d u$ futur, et ce n'est pas une vaine figure si Caton, sans doute dans cette préface, rappelait que «les ancêtres, après s'être installés pour dîner, chantaient les exploits et les mérites des grands hommes du passé». 
de Astin, ${ }^{51}$ com uma provável coletânea de preceitos práticos, o Carmen de moribus e uma compilação de ditos moralizantes.

Sem termos esgotado o considerável "catálogo" de seus feitos e escritos, reiteramos que ele, em clara postura de diligência, manteve-se por vários meios bastante engajado na promoção de certos valores romanos (labor, fortitudo, fides...). Se considerarmos que, privilegiando a atividade intelectual nos anos posteriores ao final da censura (caracterizados por certo abrandamento em seu envolvimento com a política) ${ }^{52}$ ele assim complementou até a velhice os trabalhos políticos e militares que lhe tinham cabido até então, teremos bons parâmetros a respeito da medida em que se bateu por suas ideias.

Um Catão, porém, tão centrado nos "autênticos" ideais de Roma não corresponde por inteiro ao "retrato" que divisamos nas páginas do Cato Maior. Os críticos, por sinal, têm ressaltado na imagem de Catão aqui sob foco analítico a presença de elementos "estranhos" à sua personalidade histórica, ${ }^{53}$ como o

\footnotetext{
${ }^{51}$ ASTIN, 1978, p. 183.
}

${ }^{52}$ DELLA CORTE, 1969, p. 65.

${ }^{53}$ ROBERT, 2003, p. XXI: Le personnage apparaît nimbé d'une exquise et excessive "urbanitas», consensuel à souhait, tenant à ses jeunes interlocuteurs des propos à la sagesse toute philosophique - et l'auteur le surnomme «Sapiens»./ POWELL, 2004, p. 18-19: Livy (39.40) in his memorable summary of Cato's character talks of his "asper animus" and "acerba lingua", but he was not concerned there with his private relations with his friends and juniors; while Plutarch, who is probably not independent of Cicero but at least had access to other sources, records Cato's abilities as a conversationalist ("Cato" 25). We must remember also that Cicero himself had a wide knowledge of Cato's works (cf. esp. "Brutus" 65), and was in a good position to assess his character, even though his view may sometimes seem a little distorted by his admiration for the man (grifo nosso). 
desinteressado amor pela natureza, ${ }^{54}$ o muito amiudado entusiasmo pelas obras de certos escritores gregos, ${ }^{55} \mathrm{o}$ "gosto"

${ }^{54}$ Em Cato Maior 51, a personagem de Catão declara a seus fictícios interlocutores: Me quidem non fructus modo, sed etiam ipsius terrae uis ac natura delectat. - "A mim decerto agrada não só o fruto, mas ainda o vigor e a natureza da própria terra" (trad. nossa). Inicia-se, logo na sequência, uma "enternecida" apresentação da beleza da terra "prenhe" das sementes, até que dela saiam brotos antropomorficamente aproximados de crianças e jovens humanos a crescerem. O leitor do De agri cultura catoniano, entretanto, como bem lembrado por Enzo Marmorale (Cato Maior. Bari: Laterza \& Figli, 1949, p. 184185) na comparação com o Virgílio das Geórgicas, antes depara, naquela obra, a rude e utilitarista instrumentalização de todos os fatores da vida rural... com vistas aos lucros do senhor [De agri cultura II: Auctionem uti faciat: uendat oleum, si pretium habeat; uinum, frumentum quod supersit, uendat; boues uetulos, armenta delicula, oues deliculas, lanam, pelles, plostrum uetus, ferramenta uetera, seruum senem, seruum morbosum, et si quid aliud supersit, uendat. Patrem familias uendacem, non emacem esse oportet. - "Venda em leilão: venda o azeite, se tem bom preço, o vinho e o trigo que for excedente; os bois velhos, o gado que tem um pequeno defeito, as ovelhas que têm um pequeno defeito, a lã, as peles, a carreta velha, as ferramentas velhas, o escravo velho, o escravo doente e, se algo mais for excedente, que venda. É preciso que o senhor seja vendedor, não comprador" (trad. nossa).].

${ }^{55}$ As obras de Xenofonte são especialmente evocadas pelo Cícero do Cato Maior (com as de Platão, Aristóxenes de Tarento, Áriston, Teofrasto, Heródoto, Isócrates...), mesmo quando não há explícita menção ao autor ou a seus textos (cf. "Annexe I" na edição Les Belles Lettres do Cato Maior, p. 100-101). Com efeito, o autor romano apreciara, ou mesmo traduzira, o grego desde a juventude, por suas qualidades de estilo e pelo teor moral de suas obras [POMEROY, 1995, p. 70: Cicero, who was a contemporary of Philodemus, considered Xenophon's ethical teachings so useful that he translated the "Oeconomicus" around 85 BC, when he was 20 ("De Off. 2. 87). His translation seems to have circulated widely: Varro, Columella, Pliny, and Quintilian quote or paraphrase from Cicero's version, rather than from the Greek.]. 
pela filosofia... ${ }^{56}$ Assim disposto ao flexível diálogo com outras formas de pensamento e sensibilidade que não as suas, um menos temível "Censor" surge nas páginas do Cato Maior, na verdade, por vezes imbuído de traços caracterizadores advindos do próprio Cícero.

Preferimos, diante desta constatação bem assentada no juízo crítico daqueles que se debruçaram para estudos sobre a obra, ${ }^{57}$ considerar tal estratégia construtiva da personagem de Catão antes sob o viés atualizador que sob aquele falseador. Afinal, outros eram os tempos coevos à escrita do diálogo, sendo mesmo impensável que o público do texto - em princípio, de homens tão letrados e humani quanto o autor e o dedicatário, Tito Pompônio Ático -, ${ }^{58}$ após séculos de exposição das elites de Roma a visões de mundo distintas dos cerrados limites do mos maiorum, viesse

${ }^{56}$ DE CARIA, 1974, p. 219: È stato detto che uno scritto antico sulla vecchiezza che non contenga un influsso del passo di Platone "RSP". 328e-330a. è inconcepibile: Cicerone si inserisce bene in questa 'tradizione' degli scritti perilghtwj col suo "Cato Maior", opera di cui $i$ parr. 6-8 sono una diretta ripresa del passo platonico in questione.

${ }^{57}$ NARDUCCI, 2010, p. 194-195: Proiettandosi nella figura di un anziano che aveva conservati intatti autorità e prestigio, Cicerone aveva modo di rifugiarsi in un passato ideale e di eludere la propria inattività. Nel raffigurare Catone, Cicerone si concede molte libertà rispetto alla sua immagine storicamente accertabile, e il personaggio appare addolcito e ammansito. (...) Nella vecchiaia di Catone si armonizzano in maniera perfetta il gusto per un "otium" arricchito dall'attività intellettuale, e la tenacia dell'impegno politico: le due opposte esigenze tra le quali Cicerone si era trovato ad oscillare in maniera talora contraddittoria lungo tutto l'arco della propria vita.

58 Ático (109 a 32 a.C.): trata-se do amigo de Cícero ao longo de toda sua vida e costumeiro correspondente epistolar do Arpinate nas Epistulae ad Atticum. Destacou-se pelo gosto aos estudos, tendo, ao contrário de Cícero, em geral se distanciado dos embates políticos em Roma (CORNELIVS NEPOS, 1991)./ D'AGOSTINO, 1955, p. 7-8). 
a identificar-se, de todo, com a plena rigidez catoniana. Nesse sentido, a nova urbanitas de que se reveste a versão ciceroniana de Catão o ajudaria, tanto quanto aos homens dos tempos de Cícero, a circular com maior desenvoltura numa sociedade, decerto, mais sutil e complexa, além de também pautada por outros costumes. ${ }^{59}$

O relativo ${ }^{60}$ aggionamento do protagonista do Cato Maior, porém, de modo algum inviabiliza que Cícero, nos moldes de nossa proposição desde o título deste ensaio, tenha-o contextualmente tomado, de dois modos distintos, por exemplo a ser seguido. Ora, num nível receptivo mais restrito - o do próprio autor diante do texto e o de seus pares em semelhantes conjunturas, como um também senil Ático - ${ }^{61}$ e lembrando que este diálogo foi concebido por Cícero como defesa da velhice

${ }^{59}$ Em ensaio destinado a perscrutar alguns modelos de conduta social nos tempos de Cícero, tal como perceptíveis na trama dos diálogos do Arpinate, Narducci destacou, entre outros aspectos, a delicadeza ao posicionar-se [NARDUCCI, 1984, p. 222-223: Lo spuntarsi della "uis polemica", la rinuncia a qualsiasi asprezza nel contraddittorio, la tendenza a presentare le proprie tesi solo come opinioni personali, il vezzo di schermirsi prima di assumere un'argomentazione, l'uso insistito di formule di cortesia un po' stereotipate ("quaeso", "si placet", "nisi molestum est", ecc.), l'attenzione a non mostrarsi pedanti, a non interrompere l'altrui ragionamento: da tutto questo traspare una decisa volontà di non urtare la sensibilità dell'interlocutore, di conciliarsene il gradimento.].

${ }^{60}$ ROBERT, 2002, p. 358: Cependant tout n'est pas déformé dans le portrait que brosse Cicéron de son personnage de référence. Au détour d'une répartie pesée à l'aune du bon sens, nous retrouvons notre professeur de morale, pédagogue tel qu'en lui-même. Le sujet du livre lui permet, dans ce domaine, d'y sembler plus vrai que nature.

${ }^{61}$ No ano de escrita do Cato Maior, Ático tinha sessenta e cinco anos e Cícero sessenta e dois. 
contra quatro acusações a ela imputadas pelos néscios, ${ }^{62}$ a senilidade ainda proveitosa de Catão, viril,, ${ }^{63}$ politicamente influente, talvez dado às moderadas alegrias conviviais ${ }^{64} \mathrm{e}$ capaz de suportar com coragem a morte de seu filho Marco Pórcio (152 a.C.) ${ }^{65}$ configura-se como luminoso ideal a ser

${ }^{62}$ Em Cato Maior 15, a personagem de Catão assim expõe estas acusações: Etenim, cum complector animo, quattuor reperio causas cur senectus misera uideatur, unam quod auocet a rebus gerundis, alteram quod corpus faciat infirmius, tertiam quod priuet [fere] omnibus uoluptatibus, quartam quod haud procul absit a morte. - "Com efeito, quando me acerco com a inteligência, encontro quatro motivos de parecer infeliz a velhice, o primeiro que afasta da atividade, o segundo que torna $o$ corpo mais fraco, o terceiro que priva de quase todos os prazeres, $\mathrm{o}$ quarto que não se distancia muito da morte" (trad. nossa).

${ }^{63}$ Em sua velhice - aos oitenta anos - Catão uniu-se em matrimônio com uma mulher que não era de nascimento livre e concebeu outro filho pouco depois (PARKIN, 2003, p. 198).

${ }^{64}$ PLUTARCO, 2011: Catone XXV, 3 - kkal ei gar eka s tote tw agrogeitohwn kailperixwtwn toul sunhqeij kailsundihgen i( a rwF, oultoif

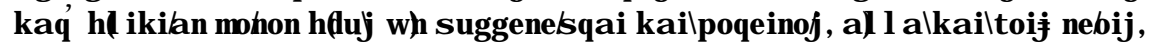
a te dh|pol I w meh empeiroj pragma twn gegonw l, pol I oij delgrammas i ka il I ogoij a kibij a kohj ent et uxhkwl. - Invitava sempre $i$ vicini e gli abitanti del paese a cui era legato e mangiava con loro in allegria. Era un compagno piecevole, richiesto non solo dagli uomini della sua età, ma anche dai giovani, perché la sua esperienza era grande ed era testimone di fatti e parole degni di essere ascoltati.

${ }^{65}$ Cícero, aludimos há pouco, perdera a filha preferida em fevereiro de 45 a.C. Sobre a resistência de Catão na morte do primeiro filho, cf. PLUTARCO, 2011: Catone XXIV, 9-11 - 0 delpres buter oj uibl et el euths estrathgw\#, ka ilmemnhta i meh a utou $\neq 0$ ol I a kij ehtoij=bibl ibij ol Katwn wl ahdrol agagou=gegonotoj, pr\#wj delkailfil os of wj l egetai thn sumf ora he enegkein, ka ilmhdeh a mbl uteroj di' a uthh eij talpol itikalgene/ s qa i. - Il suo primogenito morì quando era pretore. Nei suoi libri Catone lo ricorda spesso come un uomo onesto; si dice che sopportò il lutto con la serenità di un filosofo e la sua attività politica non ne risentì. 
seguido. Sobre a influência política de Catão, em específico, mesmo em idade avançada, note-se o comentário de Robert:

Et lorsque le Caton du «De Senectute» déclare qu'il ne fait plus la guerre, mais indique au Sénat «lesquelles il faut mener, et comment», en prenant l'exemple de Carthage ( "Je lui déclare la guerre très à l'avance, elle que je ne cesserai de craindre, tant que je n'aurai pas appris sa destruction»), il est l'exacte réplique du vrai Caton, ce «pilote» de la République que Cicéron regrettait amèrement de ne plus être depuis que César avait monopolisé le pouvoir. ${ }^{66}$

Um Catão, por outro lado, por toda a vida fiel às tradições republicanas e que, homo nouus ${ }^{67}$ como Cícero, galgara paciente todos os degraus do cursus honorum com vistas a posicionar-se legalmente no topo da esfera política pátria, jamais deixaria de exemplificar um modelo de conduta oposto ao dos novos senhores do poder em Roma. Ainda, o suicídio recente de Catão de Útica, ${ }^{68}$ amigo de Cícero, que lhe compusera um elogio, e descendente do Censor, tacitamente contribuiu para intensificar esses indiretos protestos do Arpinate contra o que lhe deve ter parecido (e, a médio prazo, acabou de fato

${ }^{66}$ ROBERT, 2002, p. 359.

${ }^{67}$ ROBERT, 2004, p. 90: Les nobles, à partir du II s. avant notre ère, ne sont plus seulement les patriciens de vieille souche, mais regroupent tous ceux, plébéiens compris, dont un membre de la famille a accompli une magistrature curule (cf. magistrats). Celui qui, le premier de sa famille, parvient à cet honneur est appelé «homme nouveau» («homo nouus»). ${ }^{68}$ Este (95 a 46 a.C.) foi o bisneto de Catão, o Velho, e tido por lendário defensor da república: refugiado na África setentrional, aonde os pompeanos se deslocaram após Farsália, sofreu derrota militar de César em Thapsus (46 a.C.), preferindo, então, um suicídio estoico em Útica a abdicar das causas políticas por que lutara (ROBERT, 2004, p. 255). 
sendo!) ${ }^{69}$ o "desencaminhar" da república pelos gestos de homens como Júlio César. Talvez, parece ele sugerir com a mera escrita do Cato Maior, se ainda dominassem em Roma líderes da têmpera dos Catões - ou dele mesmo -, o cenário político coevo não enfrentasse tantas incertezas. ${ }^{70}$

\section{Presença e participação dos exempla maiorum na instrução de Catão a Lélio e Cipião Emiliano}

Em artigo destinado a esclarecer as funções do emprego retórico dos exempla nos discursos de Cícero, Jean-Michel David deu várias mostras de que, pela compreensão dos romanos, o recurso a tal meio persuasivo ocorria nos âmbitos do probare e do mouere, isto é, com remissões ao caráter racional e emotivo do auditório:

Dans les deux cas, il traite là des moyens qui permettent une persuasion rationnelle et efficace. Le passage $d u$ "De Inuentione» $(I, 49)$ appartient au chapitre qui traite de la «confirmatio» et $l^{\prime}$ "exemplum» y est une partie du "comparabile». Celui des «Topiques» (41-45, en part. 44-45) porte, comme la quasi totalité de l'ouvrage, sur les lieux de l'argumentation et fait de

${ }^{69} \mathrm{O}$ sucessor político de Júlio César, seu sobrinho-neto Otaviano, tornou-se, na verdade, o primeiro imperador de Roma, pondo fim prático ao período republicano a partir da consolidação de seu mando (GIORDANI, 1968, p. 103).

${ }^{70}$ Para Robert, prefaciador da edição Les Belles Lettres do Cato Maior que aqui adotamos (2003, p. VII-VIII), a escrita desse diálogo, em que se enaltecem pela figura de Catão, o Velho, temos insistido, inclusive as velhas instituições republicanas, representou o único meio de resistência ideológica ainda disponível a Cícero - pela filosofia, depois do vão exemplo de Catão, o Jovem, que não o pudera fazer com efetivo sucesso agindo militar ou politicamente - contra César. 
l'«exemplum» une partie de la «similitudo». L' «exemplum» appartient donc au champ du "probare». Mais pas seulement: Cicéron le cite aussi parmi les moyens du pathétique et de l'émotion. Dans le "De Oratore», par exemple, il en évoque l'emploi à propos de l'«ornatio». (...) L' «exemplum» n'est donc pas qu'un moyen de preuve par comparaison. Il est aussi l'instant d'une émotion séductrice. C'est ce que disent d'ailleurs Quintilien dans son chapitre consacré aux «exempla»: V, 11, 5: "Similitudo adsumitur interini et ad orationis ornatum; sed illa cum res exiget; nunc ea quae ad probationem pertinent, exequar». ${ }^{71}$

Acrescentamos, aqui, que "exemplos", inclusive entendidos no sentido de relatos sobre homens históricos do passado ${ }^{72}$ e que servem, de algum modo, à persuasão, já tinham sido vistos pelo Aristóteles da Retórica como os "lugares" por excelência do gênero deliberativo, ${ }^{73}$ isto é, aquele em princípio destinado a aconselhar ao útil no seio das assembleias citadinas. Assim, desde então integraram, no plano da inuentio, isto é, da seleção dos meios argumentativos especificamente válidos para uma dada causa, $\mathrm{o}$ aparato das provas discursivas. O mesmo Aristóteles, ainda, estabelecera a divisão das provas entre aquelas de caráter "lógico"

${ }^{71}$ DAVID, 1980, p. 69 e 71.

${ }^{72} \mathrm{Na}$ verdade, caso desejássemos aproximar-nos com mais rigor da ideia de "exemplo" tal como expressa por Aristóteles na Retórica, deveríamos observar que ele distingue sob essa rubrica os relatos de "fatos anteriores" das "invenções feitas pelo orador" (ARISTÓTELES, s.d., p. 143 - livro II, cap. XX, 1).

${ }^{73}$ REBOUL, 2004, p. 46: O judiciário, que dispõe de leis e se dirige a um auditório especializado, utiliza de preferência raciocínios silogísticos (entimemas), próprios a esclarecer a causa dos atos. O deliberativo, dirigindose a um público mais móvel e menos culto, prefere argumentar pelo exemplo, que, aliás, permite conjecturar o futuro a partir dos fatos passados: Dionísio pede uma guarda; ora, todos os futuros tiranos conhecidos da história pediram uma guarda; logo, Dioniso vai tornar-se tirano (1357 b). 
(abrangendo "entimemas" e exemplos), "ético" e "patético": correspondem as primeiras àquelas baseadas em raciocínios, respectivamente, dedutivos e indutivos; o ethos, por sua vez, é a imagem do orador tal como construída em seu discurso; o pathos, enfim, que diz respeito aos ouvintes, corresponde às emoções neles despertadas pelo orador com peculiares objetivos. ${ }^{74}$

Ora, se os exempla também se prestam, na visão dos latinos, a mouere, isto é, a despertar emoções sobre um auditório dado, reiteramos, com base nos preceitos Aristotélicos da Retórica, que em alguma medida partilharam, em seu fazer oratório, de atributos das provas "patéticas", além daqueles das "lógicas". ${ }^{75}$ Por outro lado, o testemunho supracitado da Rhetorica ad Herennium, que trata dos exempla em seu quarto livro, exatamente o destinado à abordagem da elocutio, ou efetiva realização estilística dos discursos ${ }^{76}$ parece deslocar a consideração do mesmo elemento retórico do terreno das provas para o das figuras. De fato, neste livro, eles são explicados ao lado da prosopopeia (conformatio, 66), da hipérbole (exsuperatio, 67) e da evidência (demonstratio, 68), por exemplo.

Outro estudioso da Antiguidade, J. G. F. Powell, comentador da edição de Cambridge do Cato Maior, também incluiu os muitos exempla de que se vale Cícero, precisamente, neste diálogo, entre os meios oratórios de sua composição. Para o crítico anglófono, a esse respeito,

The method of argument is often loose, proceeding by illustrations, examples and appeals to common sense, rather than strict logic. Philosophical arguments are alluded to or summarized, rather than

\footnotetext{
${ }^{74}$ REBOUL, 2004, p. 47-49.

75 REBOUL, 2004, p. 62 (em que o estudioso menciona a vinculação antiga do pathos ao objetivo do mouere - "comover" -, do logos ao do probare/ docere - "ensinar" - e do ethos ao do delectare - "agradar"). 76 PERNOT, 2000, p. 283.
} 
expounded in detail (see e.g. par. 4 on self-sufficiency; par. 46 on moderation; par. 47 on the meaning of "carere"; par. 71 on the equation of "good" with "natural"; par. 78 on immortality, with arguments reproduced from Plato (...). The many examples and anecdotes give the work a distinctive flavor: again the technique derives from rhetorical practice. A number of them are simply Cicero's favourite "exempla" of old Roman virtue, some without any special appropriateness to the context of old age, while others are used to illustrate specific points: long life, activity in old age, memory, physical strength, courage in mourning, and so on. ${ }^{77}$

Em que pese ao juízo algo severo de Powell, é inegável que a recorrência aos exempla pelo Catão da obra aqui em pauta contribui para imprimir às linhas do texto traços de funcionalidade persuasiva e colorido de expressão, como tentaremos demonstrar a seguir com base em casos concretos. Os primeiros exempla que poderíamos aludir correspondem, em complexo agenciamento de dados, àqueles vinculados a Quinto Fábio Máximo Cunctátor, dito "o Temporizador" porque, após o início da Segunda Guerra Púnica, quando Roma se encontrava sem forças pelo conflito, permitiu-lhe refazer-se postergando a retomada dos combates. ${ }^{78}$ Assim, o fictício Catão do diálogo inicia-lhe a evocação situando a personagem no tempo: esse responsável pela retomada romana de Tarento (209 a.C), com efeito, teria sido caro como um jovem companheiro ao protagonista na própria mocidade deste, quando, porém, aquele já era idoso; ${ }^{79}$ ainda, menciona-

${ }_{77}$ POWELL, 2004, p. 9-10.

${ }^{78} \mathrm{Cf}$. nota 23 de Jean-Noël Robert à passagem em questão, na edição Les Belles Lettres do texto (Cato Maior 10).

${ }^{79}$ Cf. Cato Maior 10: Senem adulescens ita dilexi ut aequalem. - "Sendo ele velho, em minha juventude gostei dele como que de alguém de mesma idade" (trad. nossa). 
se que o primeiro consulado de Quinto antecedeu um ano o nascimento de Catão, o qual se dera em 234 a.C.; devido a um erro histórico de Cícero, que esse o teria acompanhado como jovem recruta a Cápua e, depois, a Tarento. ${ }^{80}$ Enfim, conta-nos Catão, durante o consulado de Tuditano e Cetego (204 a.C.), sendo ele mesmo questor, Quinto apoiava a lei Cíncia, "sobre os presentes e remunerações" ${ }^{81}$ já em idade bastante avançada. ${ }^{82}$

Na continuidade, Catão afirma o valor humano deste "herói" nos termos que seguem:

11. Tarentum uero qua uigilantia, quo consilio recepit! Cum quidem me audiente Salinatori, qui, amisso oppido, fuerat in arce, glorianti atque ita dicenti: "Mea opera, Q. Fabi, Tarentum recepisti" - "Certe", inquit ridens; "nam nisi tu amisisses, numquam recepissem". Nec uero in armis praestantior quam in toga: qui, consul iterum, Sp. Caruilio collega quiescente, C. Flaminio tribuno plebis quoad potuit restitit, agrum Picentem et Gallicum uiritim contra senatus auctoritatem diuidenti; augurque cum esset, dicere ausus est optumis auspiciis ea geri quae pro rei publicae salute gererentur, quae contra rempublicam ferrentur contra auspicia ferri. 12. Multa in eo uiro praeclara cognoui, sed

${ }^{80} \mathrm{Cf}$. nota 25 de Jean-Noël Robert à passagem em questão, na edição Les Belles Lettres do texto (Cato Maior 10): Cicéron commet deux inexactitudes quant à la carrière de Caton: il n'était pas à Capoue, mais en Sicile, cette année là, et probablement pas à Tarente en - 209.

${ }^{81}$ A lei mencionada, que foi proposta pelo tribuno M. Cíncio Alimento, proibia aos advogados receberem presentes e honorários; além disso, vetava o recebimento de presentes quaisquer, por quaisquer pessoas, acima de um dado valor (a não ser na troca entre parentes); cf. comentário de Powell à passagem em questão, na edição de Cambridge do Cato Maior, p. 124.

${ }^{82}$ Cf. Cato Maior 10: Ille admodum senex suasor legis Cinciae de donis et muneribus fuit - "Bem velho, deu ele apoio à lei Cíncia sobre os presentes e remunerações" (trad. nossa). 
nihil admirabilius quam quo modo ille mortem fili tulit, clari uiri et consularis; est in manibus laudatio, quam cum legimus, quem philosophum non contemnimus? Nec uero ille in luce modo atque in oculis ciuium magnus, sed intus domique praestantior; qui sermo, quae praecepta, quanta notitia antiquitatis, scientia iuris augurii! Multae etiam, ut in homine Romano, litterae: omnia memoria tenebat non domestica solum sed etiam externa [bella]. Cuius sermone ita tum cupide fruebar quasi iam diuinarem, id quod euenit, illo exstincto fore unde discerem neminem. ${ }^{83}$

${ }^{83}$ Cf. Cato Maior 11-12: "Tarento, na verdade, com que cuidado, com que prudência recobrou! Falou rindo a Salinátor que, perdida a cidade, ficara na fortaleza, e assim se vangloriava e dizia em minha presença: 'Por minha causa, Quinto Fábio, recobraste Tarento' 'Decerto, pois se tu não a tivesses perdido, eu jamais a teria recobrado'. Nem, na verdade, foi menos ilustre na toga que nas armas: ele, cônsul pela segunda vez, embora se abstivesse seu colega Espúrio Carvílio, resistiu até poder ao tribuno da plebe $C$. Flamínio, que repartia por cabeça os territórios do Piceno e da Gália contra a autoridade senatorial; sendo ele áugure, ousou dizer que com os melhores auspícios se fazia o feito pela salvação da república, mas que o feito contra a república se fazia contra os auspícios. Muito de notável conheço sobre este homem, mas nada mais admirável do que o modo como suportou a morte do filho, varão distinto e personagem consular; circula seu elogio (fúnebre) e, quando o lemos, que filósofo não desprezamos? Nem, na verdade, apenas à luz do dia e sob os olhos dos concidadãos foi grande, mas superior na intimidade e em casa; que conversa, que preceitos, quanto saber do passado e conhecimento do direito augural! E ainda, muitas letras para um homem romano: guardava na memória não só todas as guerras locais, mas também as do estrangeiro. Eu então desfrutava avidamente da conversa dele como que adivinhando, o que veio a concretizar-se, mestre algum haver de ter após sua morte" (trad. nossa). 
Vários são, na verdade, as anedotas / exempla de que Catão se serve no trecho a fim de oferecer a seus jovens interlocutores ${ }^{84}$ uma imagem positiva de Quinto Fábio. De início, no exemplum relativo à retomada de Tarento, que um covarde e inepto Salinátor perdera para o inimigo, sobressai-se a dupla astúcia do elogiado, ao vencer militarmente com base no "cuidado" e na "prudência", avisa-nos Catão, e diante do espírito mais lento do outro. Evidentemente, a recorrência, para relatar a interlocução entre Quinto e Salinátor, ao discurso direto em muito contribui para intensificar a força de apresentação da personagem - note-se, sobretudo, a irônica quebra de expectativa posterior a certe/ "decerto" -, pois parece, em certo sentido, pô-la diante de nossos olhos e ouvidos. Quando se fala de sua resistência à mudança social proposta pelo tribuno da plebe C. Flamínio, no sentido da conservação das terras do ager publicus em efetivo poder da Ordem senatorial, por outro lado, tocamos num ponto de grande importância para a construção da imagem exemplar de Quinto Fábio, já que, desse modo, ele se mostra a Lélio e Cipião Emiliano, assim como Catão, Cícero ${ }^{85}$ e tantos tradicionalistas de Roma, "prudente" inimigo de quaisquer res nouae ("revoluções").

Imediatamente, o exemplum vinculado ao augurado de Quinto e ao que, de novo, ousara de imprevisto dizer diante de uma dada circunstância, evidencia a paradoxal imagem de alguém, antes de mais nada, devotado à república. Sabemos, com efeito, que o cargo aludido nesta pequena anedota relacionavase à indicação aos políticos e oficiais dos fatores fastos ou

${ }^{84} \mathrm{Na}$ data fictícia do diálogo, que se passa em 150 a.C., um ano antes da morte de Catão, aos oitenta e cinco anos, Cipião Emiliano e Lélio estavam na faixa dos trinta anos.

${ }^{85}$ WOOD, 1991, p. 112: Cicero obviously has no desire to equalize property. He constantly and vigorously attacks agrarian laws that would redistribute property, most of which he believes are designed by demagogues to plunder the rich for the sake of the poor. 
nefastos a incitarem ou demoverem da realização de dadas tarefas, como o início de assembleias ou campanhas. ${ }^{86}$ Assim, os áugures deveriam corresponder a meros intermediários entre a vontade dos deuses e as intenções humanas, mas Quinto Fábio parece, em mostra de óbvio pragmatismo, ter sempre tido para si que nada de nocivo ao status quo republicano seria recomendável... apesar de quaisquer sinais divinos (omina). Se neste ponto, portanto, ele está algo distanciado do ideal do mos maiorum, que preconizava, sabemos, o acato cívico às práticas religiosas dos ancestrais, ${ }^{87}$ por outro lado se exime estribado em seu ethos de servidor da coletividade e amante das instituições políticas tradicionais. Não podemos deixar de lembrar, ainda, a propósito desta e de outras ousadias da fala de Quinto, que Catão também se notabilizou pela dureza e cru imediatismo da linguagem, de modo afim à manifestação do depois chamado italum acetum ("mordacidade itálica"), quando necessário no trato enérgico com os concidadãos. ${ }^{89}$

${ }^{86}$ CAMPBELL, 2011, p. 61: Signs and portents were respected and special colleges of priests had the job of interpreting them. The Augurs were principally responsible for maintaining augural lore and replying to questions from officials; they could also take the auspices before major undertakings and had the right of making a binding pronouncement of adverse omens that had appeared unsought; this had the effect of ending any assembly in progress.

${ }^{87}$ Cf. supra nota 11 e imediações textuais de seu emprego.

${ }^{88}$ Trata-se, na verdade, de expressão proveniente da sátira I, VII, 32 de Horácio, indicando sourness of disposition and sharpness of wit, na definição do dicionário latino-inglês de Oxford [GLARE, 1968, p. 29]. ${ }^{89}$ AGACHE, 1980, p. 95-96: Sa vie durant, «il ne cessa de s'attirer des haines», signale Cornélius Népos, et sa mort, sous-entend-il, leur laissa libre cours. Une épigramme non datée témoigne de la virulence de ces attaques: «roux, les yeux pers, et prompt à mordre (grifo nosso), Porcius, mort, n'est pas admis aux enfers par Perséphone». La même image nous est transmise par Tite-Live: «Caton, dit-il, avait passé sa vie entière à poursuivre de ses aboiements la grandeur de Scipion l'Africain». 
O incidente brevemente relatado da resistência à dor quando da morte do filho, por sua vez, com a dupla ressonância de ecoar semelhante desafio por parte de Catão e de Cícero, como dissemos, ${ }^{90}$ talvez se constitua na passagem, nos termos de David em seu artigo supracitado, mais apta a mouere, isto é, a comover do ponto-de-vista afetivo o público fictício - Lélio e Cipião Emiliano - ou "real" do diálogo, sobretudo, no último caso, quando consideramos a primeira recepção do texto na sociedade romana. ${ }^{91}$ Com efeito, quando da fictícia localização temporal da obra ${ }^{92}$ ou de sua escrita, ${ }^{93}$ Catão, o Velho, e Cícero tinham respectivamente perdido filhos dois e um ano antes, mas tentaram tolerá-lo com energia, de maneira condizente com a coragem prévia de Quinto Fábio em idêntico quesito. Ora, assim assimilados em sua dor ao exemplum daquele, seriam suscetíveis, imaginamos, de despertar simultaneamente a compaixão ${ }^{94}$ e a admiração dos ouvintes próximos. Isso significa, sobre o aspecto persuasivo de tal passagem, que, por um ou outro afeto, o público, seja ele qual for, é levado a solidarizar-se com homens capazes de resistir a situação tão adversa.

${ }^{90}$ Cf. supra nota 65.

${ }^{91} \mathrm{Na}$ verdade, a difusão do Cato Maior deve originalmente ter privilegiado o círculo próximo dos pares sociais, ou amigos, como Tito Pompônio Ático, do autor.

${ }^{92}$ Cf. supra nota 84.

${ }^{93}$ Cf. supra nota 18.

${ }^{94}$ Sobre o tratamento do afeto da compaixão, cf. livro II, VIII, 15 da Retórica aristotélica: kstw dhlel eoj I uph tij epilfa inomen\% kak\%= f qartik\% = ll uphr\% pa qei hltw a utou=tina (...) - Seja, então, a compaixão certo pesar por um mal que se mostra destrutivo ou penoso, e atinge quem não o merece, mal que poderia esperar sofrer a própria pessoa ou um de seus parentes (ARISTÓTELES, 2003, p. 53). 
Depois, a menção aos saberes algo eruditos de Quinto configura a preocupação da personagem com munir-se de conhecimentos de utilidade para a boa condução de si e dos negócios comuns, segundo parâmetros que já tinham antes guiado os maiores. De fato, ocupar-se de adquirir conhecimentos como aqueles do direito (augural) e da história (pátria ou estrangeira) visava, na compreensão de tradicionalistas como o próprio Catão, a favorecer a boa conduta prática dos cidadãos quando deparassem situações afins às experimentadas pelos ancestrais, ${ }^{95}$ e de que eles souberam sair-se com a destreza minimamente indispensável para não comprometerem a sobrevivência do Estado.

Todos esses positivos exempla, enfim, inserem-se logo no início de um diálogo filosófico combativo à ideia da velhice como época, sob vários aspectos, inferior ou menos feliz da vida humana. ${ }^{96}$ Dessa maneira, acabam logicamente provando, por analogia, ${ }^{97}$ que, se uma personagem "heroica" como Quinto Fábio viveu como viveu e foi ativa, prestigiada ou mesmo amada até o fim de seus longos dias - haja vista a algo enternecida declaração catoniana do término do trecho, sobre a falta que lhe fez este amigo à formação após sua morte -, todos os que tiverem coragem para conduzir-se como ele, em geral harmonia com os princípios do mos maiorum... também alcançarão uma

${ }^{95}$ GRIMAL, 1994, p. 120: La connaissance du passé importe à ceux qui ont la responsabilité $d u$ présent et $d u$ futur, et ce n'est pas une vaine figure si Caton, sans doute dans cette préface, rappelait que «les ancêtres, après s'être installés pour dîner, chantaient les exploits et les mérites des grands hommes du passé». Pour lui, l'Histoire continue, en les modernisant, les «carmina conuiualia».

${ }^{96}$ Cf. supra nota 62.

${ }^{97}$ DAVID, 1980, p. 11: Il est certain qu'au moins par analogie, le raisonnement intervient dans ce processus. 
velhice proveitosa. O próprio prestígio de Catão, formado por Quinto Fábio, pela letra do texto, parece confirmá-lo.

Mas, à maneira de uma ilustração das variadas possibilidades do emprego persuasivo dos exempla, notamos que nem sempre esses correspondem a aspectos positivos, prestando-se então a espelhos de conduta para aqueles desejosos de agir em conformidade com parâmetros aprovados socialmente:

27. Ne nunc quidem uiris desidero adulescentis - is enim erat locus alter de uitiis senectutis - non plus quam adulescens tauri aut elephanti desiderabam. Quod est eo decet uti et quidquid agas agere pro uiribus. Quae enim uox potest esse contemptior quam Milonis Crotoniatae? Qui, cum iam senex esset athletasque se exercentis in curriculo uideret, adspexisse lacertos suos dicitur illacrimansque dixisse: "At hi quidem mortui iam sunt". - Non uero tam isti quam tu ipse, nugator! Neque enim ex te umquam es nobilitatus, sed ex lateribus et lacertis tuis. Nihil Sex. Aelius tale, nihil multis annis ante Ti. Coruncanius, nihil modo $P$. Crassus, a quibus iura ciuibus praescribebantur; quorum usque ad extremum spiritum est prouecta prudentia. ${ }^{98}$

${ }_{98}$ Cf. Cato Maior 27: "Nem sequer sinto agora falta das forças da juventude - essa, com efeito, era a segunda queixa sobre os males da velhice -, não mais do que, jovem, sentia falta das do touro ou do elefante. Convém servir-se do que houver e, o que quer que se faça, fazer segundo as forças. Que palavras, na verdade, podem ser mais desprezíveis que as de Milão Crotoniata? Ele, sendo já velho e vendo atletas a se exercitarem na pista de corrida, contam ter examinado os próprios braços e dito a chorar: 'Estes decerto já estão mortos'. - Não, de fato, tanto estes quanto tu mesmo, tolo! Nem, na verdade, jamais foste honrado por ti, mas por teus flancos e braços. Nada assim Sex. Élio, nada, muitos anos antes, Ti. Coruncânio, nada há pouco P. Crasso, pelos quais leis eram formuladas para os cidadãos; o bom-senso deles se prolongou até o último suspiro" (trad. nossa). 
O excerto acima, que se insere com outros na refutação catoniana à velhice como tempo de necessária debilidade, traz, notamos, o exemplum negativo - a ser evitado - de Milão Crotoniata, a que se seguem aqueles positivos de Sexto Élio, Tibério Coruncânio e Crasso, legisladores da república romana em tempos distintos, mas sempre capazes de dar o testemunho do próprio vigor até idade avançada. Tal vigor, necessariamente, não se identifica com aquele corporal, de cuja falta se lamentara até as lágrimas um néscio Milão, mas com o do espírito, em alguns casos capaz de sobrepujar os males da relativa debilidade física para trazer ao homem idoso as luzes mais perenes da inteligência. Embora não faltem anedotas, no próprio contexto do Cato Maior, relativas a anciãos inclusive capazes de esforços do corpo na velhice, tamanha sua tenacidade diante do inexorável correr dos anos, ${ }^{99}$ claro está que essa obra e os costumes romanos, em geral, tenderam a situar o vigor humano numa escala de valores em que o espírito, em sua acepção da capacidade mental dos indivíduos, levou vantagem nos embates contra o físico.

Semelhante valoração justifica, assim, além do desmerecimento da visão de mundo de Milão, a próprio peso ancestral, na sociedade romana, da auctoritas ("prestígio") dos senadores, palavra latina em óbvia conexão com senex ("ancião") no mesmo idioma e evocativa do caráter ponderado dos juízos daqueles que o tempo amadureceu. ${ }^{100}$ Quer positiva, quer negativamente, pois, os exemplos, desta feita compreendidos sob seu aspecto de artefatos retóricos - não de figuras humanas em "tudo" modelares, como o próprio Catão -, contribuem

${ }^{99}$ Cf., em Cato Maior 60, o caso extremo de Marco Valério Corvino (nascido em 371 a.C.), que prolongara a lida agrícola, segundo a tradição, até seu centenário.

100 ERNOUT e MEILLET, 2001, p. 613: Sénat, assemblée des anciens, cf. gr. gerousiti de getwn. 
para atribuir à fala da mesma personagem óbvios ecos do consagrado ideário dos maiores. Por isso, como dissemos, apesar do relativo aggiornamento ou "humanização" do Censor nas páginas do Cato Maior, não se exclui aqui a grande afinidade ideológica com o tradicionalismo, conforme temos delineado como amiudada tendência da cultura romana desde o início destas nossas proposições.

\section{Referências bibliográficas}

AGACHE, S. Caton le Censeur, les fortunes d'une légende. In: CHEVALLIER, R. (org,). Colloque histoire et historiographie. Clio. Paris: Les Belles Lettres, 1980, p. 71-107.

ANDRÉ, J.-M. La philosophie à Rome. Paris: Presses Universitaires de France, 1977.

ARISTÓTELES. Arte retórica. Arte poética. Trad. de Antônio Pinto de Carvalho. Rio de Janeiro: Ediouro, s.d.

ARISTÓTELES. Retórica das paixões. Trad. de Ísis Borges da Fonseca. São Paulo: Martins Fontes, 2003.

ASTIN, A. E. Cato the Censor. Oxford: Clarendon Press, 1978.

BORNECQUE, H.; MORNET, D. Roma e os romanos. Trad. de Alceu Dias Lima. São Paulo: E.P.U./ Edusp, 1976.

BOSCHERINI, S. Lingua e scienza greca nel "De agri cultura" di Catone. Roma: Edizioni dell'Ateneo, 1970.

CAMPBELL, B. The Romans and their world. A short introduction. New Haven/ London: Yale University Press, 2011.

CATO; VARRO. On agriculture. With an English translation by $\mathrm{H}$. D. Hooper. Cambridge, Massachusetts/ London, England: Harvard University Press, 1999.

CICERO. Cato Maior de Senectute. Edited with introduction and commentary by J. G. F. Powell. Cambridge: University Press, 2004. 
CICÉRON. De la vieillesse. Texte établi et traduit par P. Wuilleumier, introduction, notes et annexes de J.-N. Robert. Paris: Les Belles Lettres, 2003.

CICÉRON. Rhétorique ad Hérennius. Texte révu et traduit par Henri Bornecque. Paris: Garnier, s.d.

CORNELIVS NEPOS. Three lives: Alcibiades, Dion, Atticus. Edited by R. Roebuck. London: Bristol Classical Press, 1991.

D'AGOSTINO, V. Introduzione. In: CICERONE. Cato Maior de Senectute. Torino: Società Editrice Internazionale, 1955, p. 3-34.

DAVID, J.-M. «Maiorum exempla sequi»: l' «exemplum» historique dans les discours judiciaires de Cicéron. Mélanges de l'École française de Rome. Moyen-Âge, temps modernes. Rome, vol. XCII, n. 92-91, p. 67-86, 1980.

DE CARIA, F. Cicerone "Cato Maior" 6-8 e Platone "RSP". 328e330a. Vichiana. Napoli, fasc. I-II, p. 219-226, 1974.

DELLA CORTE, F. Catone Censore. La vita e la fortuna. Firenze: La Nuova Italia, 1969.

Dicionário Houaiss da língua portuguesa. $1^{a}$. edição. Rio de Janeiro: Objetiva, 2009.

ERNOUT, A.; MEILLET, A. Dictionnaire étymologique de la langue latine. Paris: Klincksieck, 2001.

GALE, M. R. Lucretius and the didactic epic. London: Bristol Classical Press, 2001.

GIORDANI, M. C. História de Roma. 16ª . ed. Petrópolis: Vozes, 1968. GLARE, P. G. (org.). Oxford Latin dictionary. Oxford: Clarendon Press, 1968.

GRIMAL, P. Cicéron. Paris: Fayard, 1986.

GRIMAL, P. A civilização romana. Trad. de Isabel de St. Aubyn. Lisboa: Edições 70, 2009.

GRIMAL, P. La littérature latine. Paris: Fayard, 1994. 
HORACE. Satires. Texte établi et traduit par F. Villeneuve, introduction et notes d'O. Ricoux. Paris: Les Belles Lettres, 2002.

LE GLAY, M.; VOISIN, J.-L.; LE BOHEC, Y. A history of Rome. Translated by Antonia Nevill. Malden, MA/ Oxford/ Carlton, Victoria: Blackwell Publishing, 2008.

LEUMANN, M. La lingua poetica latina. In: LUNELLI, A. (org.). La lingua poetica latina. Bologna: Pàtron, 1988, p. 131-178.

LVCRETI. De rerum natura. Recognouit breuique adnotatione critica instruxit Cyrillus Bailey. Oxonii: E Typographeo Clarendoniano, 2009.

MARMORALE, E. Cato Maior. Bari: Laterza \& Figli, 1949.

MARTIN, R. Recherches sur les agronomes latins et leurs conceptions économiques et sociales. Paris: Les Belles Lettres, 1971.

MILES, G. B. Virgil's "Georgics". A new interpretation. Berkeley/ Los Angeles: University of California Press, 1980.

NARDUCCI, E. Il comportamento in pubblico: Cicerone, "De officiis" I 126-149. Maia. Bologna, fasc. I, anno 36, p. 222-223, gennaio-aprile 1984.

NARDUCCI, E. Introduzione a Cicerone. Terza edizione. Roma/ Bari: Laterza, 2010.

PARKIN, T. G. Old age in the Roman world. Baltimore/ London: The Johns Hopkins University Press, 2003.

PEREIRA, V. S. Inveja e emulação em Plínio-o-Moço. In: Symbolon II: inveja e emulação. Porto: Faculdade de Letras da Universidade do Porto, 2010, p. 102-124.

PERNOT, R. La rhétorique dans l'Antiquité. Paris: Le Livre de Poche, 2000.

PLUTARCO. Vite parallele. Aristide e Catone. A cura di Barbara Scardigli. Milano: Rizzoli, 2011.

POCIÑA, A. Épica y teatro. In: CODOÑER, C. (org.). Historia de la literatura latina. Madrid: Cátedra, 2007, p. 13-70. 
POMEROY, S. B. The "Oeconomicus" after Xenophon. In: XENOPHON. Oeconomicus. A social and historical commentary. With a new English translation by Sarah B. Pomeroy. Oxford: Clarendon Press, 1995, p. 68-90.

POWELL, J. G. F. Introduction. In: CICERO. Cato Maior de Senectute. Edited with introduction and commentary by J. G. F. Powell. Cambridge: University Press, 2004, p. 1-51.

REBOUL, O. Introdução à retórica. Trad. de Ivone Castilho Benedetti. São Paulo: Martins Fontes, 2004.

ROBERT, J.-N. Caton, ou le citoyen. Paris: Les Belles Lettres, 2002.

ROBERT, J.-N. Introduction. In: CICÉRON. De la vieillesse. Texte établi et traduit par P. Wuilleumier, introduction, notes et annexes de J.-N. Robert. Paris: Les Belles Lettres, 2003, p. VII-XXV.

ROBERT, J.-N. Rome. Paris: Les Belles Lettres, 2004.

ROCHA PEREIRA, M.-H. Estudos de história da cultura clássica. II Volume - Cultura romana. $4^{\mathrm{a}}$. ed. Lisboa: Gulbenkian, 2009.

TOSI, R. Dicionário de sentenças latinas e gregas. Trad. de Ivone Castilho Benedetti. São Paulo: Martins Fontes, 2000.

WOOD, N. Cicero's social and political thought. Berkeley/ Los Angeles/ London: University of California Press, 1991. 


\section{Resumo}

Neste artigo, gostaríamos de discutir como Cícero emprega "exemplos" no Cato Maior a fim de apresentar-nos uma imagem paradigmática do protagonista, Catão, o Velho, e utiliza exempla retóricos como meio de construção da mesma personagem, através de sua fala ficcional. Nos dois casos, argumentamos que ele quis manter-se em posição de defensor das tradições de Roma, como definidas pelo mos maiorum.

\section{Abstract}

In this article, we would discuss how Cicero employs "examples" in Cato Maior in order to present us a paradigmatic image of the protagonist, Cato the Elder, and uses rhetorical exempla as a means for building the same character through his fictional speech. In both cases, we argue that he wanted to remain in a position of defender of the traditions of Rome, as defined by mos maiorum. 